УДК 159.928

DOI:

Лариса Карпова, кандидат педагогічних наук, доиент, викладач кафедри прикладної психологї Харківського національного університету імені В.Н. Каразіна

\title{
ДОСЛІДНИЦЬКА КОМПЕТЕНТНІСТЬ ВЧИТЕЛЯ НОВОЇ УКРАЇНСЬКОЇ ШКОЛИ
}

У статті наведені результати аналізу поняття “дослідницька компетентність вчителя”. Встановлено, що дослідницька компетентність входить до складу ключових. Визначено, щуо формування дослідницької компетентності педагогів є необхідною умовою їхнього становлення у Новій украӥнській школі. Аналіз трактувань поняття показав, що більшість визначень не враховують особистість дослідника, тим самим нівелюючи суть компетентнісного підходу. Отже, сформульовано авторське визначення поняття “дослідницька компетентність вчителя” в умовах реалізації дослідницької парадигми розвитку освіти.

Ключові слова: дослідницька компетентність; Нова украйнська школа; індивідуальна дослідницька траєкторія; дослідницька парадигма.

Лim. 11.

Larysa Karpova, Ph.D.(Pedagogy), Associate Professor, Senior Lecturer of the Applied Psychology Kharkiv V. N. Karazin National University

\section{RESEARCH COMPETENCE OF TEACHERS OF NEW UKRAINIAN SCHOOL}

The relevance of the research is determined by the need to search for the content of the teacher's research competence in the context of reforming the education system and introducing the New Ukrainian School. The purpose of the study is to define the idea of research competence of the teacher in the conditions of implementation of the research paradigm of education development. It has been established that in the education system a new paradigm is being approved - the research one, which concentrates on ensuring the unity of the educational and research processes. This approach will allow students to systematically cover research work, both, in the framework of individual academic subjects and studies, which will be based on interdisciplinary connections. As a result, this will ensure the mastery of the methods of self-acquisition and assimilation of knowledge by students and will bring to a new level of demand of the formation of an individual research trajectory in teachers in their professional activities. The analysis of scientific information allowed establishing that research competence is part of the key. It is proved that the formation of the research competence of teachers is a necessary condition for their formation in the New Ukrainian School. An analysis of the interpretation of the concept showed that most definitions do not take into account the personality of the researcher, thereby leveling the essence of the competence approach. The article presents the formulation of the author's definition of the concept "research competence of the teacher", which is understood by integrating the self-professional quality, reflecting the motivation for scientific research, proficiency in the methodology of research practice, maturity of personality-relevant qualities as conditions for the realization of their individual research path and attractant system for students for teaching and research work. Research methods: theoretical. The theoretical meaning consists in the formation of the author's definition of the concept "teacher's research competence". Practical value: materials can be used in the process of preparing teachers for the implementation of research activities.

Keywords: research competence; New Ukrainian School; an individual research trajectory, research paradigm.

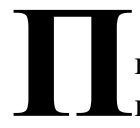

остановка проблеми. Однією 3 провідних тенденцій розвитку вітчизняної освіти є посилення уваги до якості підготовки вчителів до дослідницької роботи. Зокрема у Законі “Про освіту” (2017р.) підкреслюється, що державна політика у сфері освіти формується і реалізується на основі наукових досліджень. Серед принципів освітньої діяльності тут зазначаються такі, як науковий характер освіти, іï інтеграція у міжнародний освітній та науковий простір та інші. Практичне впровадження цих основ вже закладене у типових освітніх програмах Нової української школи. Їх аналіз показав, що змістовно вони спрямовані на формування в учнів компетентностей через “формування допитливості, прагнення шукати i пропонувати нові ідеї, самостійно чи в групі спостерігати та досліджувати, формулювати припущення і робити висновки на основі проведення дослідів, пізнавати себе і навколишній світ шляхом спостереження та дослідження" [10, 2]. Таким чином, у системі освіти відбувається утвердження нової парадигми - дослідницької, яка концентрується на забезпеченні єдності навчального та дослідницького процесів. Такий підхід дозволить системно охопити тих, хто навчається, дослідницькою роботою як у межах окремих навчальних предметів, так і досліджень, 
які базуватимуться на міжпредметних зв'язках. У підсумку це забезпечить володіння способами самостійного здобування та засвоєння знань учнями й виведе на новий щабель затребуваності питання формування у педагогів індивідуальної дослідницької траєкторії в професійній діяльності.

Як підтвердив аналіз першоджерел (О. Бережнова, В. Болотов, Л. Бурчак, Л. Голуб, М. Головань, І. Зимня, Н. Кузьміна, Д. Мацько), необхідною умовою реалізації дослідницької парадигми освіти є дослідницька компетентність вчителя. Особливого значення ії сформованість набуває у зв'язку з розвитком авторських шкіл, проведення всеукраїнського експерименту за темою “Теоретико-методологічні засади моделювання розвитку авторських шкіл" на базі загальноосвітніх закладів України тощо. Так, основним завданням педагогічних колективів авторських шкіл та педагогів, які зосереджують увагу на роботі $з$ обдарованими дітьми, є розроблення та впровадження нових освітніх моделей, нового змісту, методів, форм, засобів навчання та менеджменту; продукування та апробація нових педагогічних систем й технологій, що потребує проведення значної експериментальної роботи. Але опитування педагогів виявило їхню недостатню орієнтацію у різноманітті сучасних наукових підходів та концепцій дослідницької роботи в школі, існування проблем у використанні методів дослідження та організації дослідницької роботи на рівні сучасних вимог.

Аналіз основних досліджень і публікацій. Аналіз психолого-педагогічних публікацій свідчить про підвищення інтересу науковців до питання сформованості дослідницької компетентності у педагогів сучасної школи. Водночас аналіз робіт О. Норкіної, Ю. Риндіної, С. Сисоєвої, К. Степанюк, А. Хуторського, Т. Шкеріної, В. Яценко та інших дає підстави стверджувати, що поняття “дослідницька компетентність педагога” все ще є дискусійним. Сьогодні питання формування дослідницької компетентності вчителя потребує чіткого визначення його сутності в умовах реалізації дослідницької парадигми розвитку освіти 3 тим, щоб дати початок для обгрунтування методологічної платформи формування учителя Нової української школи.

Метою статті $\epsilon$ визначення сутності дослідницької компетентності вчителя в умовах реформування системи освіти та реалізації концепції Нової української школи.

Виклад основного матеріалу дослідження. Поняття “компетентність" є основною категорією компетентнісного підходу в навчанні, яке у Рамці кваліфікацій Свропейського простору вищої освіти (2005 р.), визначається як динамічне поєднання знань, умінь і здатностей.

В Україні утвердження компетентнісного підходу в освіті супроводжується дискусіями щодо сутності поняття “компетентність”, розмежуванням компетентностей і компетенцій. У затвердженій Кабінетом Міністрів України Національній рамці кваліфікацій дається визначення, відповідно до якого, компетентність - це здатність особи до виконання певного виду діяльності, що виражається через знання, розуміння, уміння, цінності інші особистісні якості. При цьому, дослідницька компетентність входить до складу ключових, тобто таких, що необхідні для виконання будь-якої професійної діяльності (В. Болотов, І. Зимня, А. Хуторський). Завдяки їй реалізується уміння критичного мислення та рефлексивного аналізу, швидке адаптування особистості у соціальному та професійному середовищах, розвиваються здатність досліджувати проблеми, висувати судження на основі виважених даних, приймати рішення на раціональних засадах.

Розглянемо вимоги до вчителя у відповідності до концептуальних положень Нової української школи. Серед дев'яти ключових компонентів формули Нової української школи виділимо такі, що безпосередньо стосуються особистості вчителя, а саме: умотивований учитель, який має свободу творчості й розвивається професійно; педагогіка, що грунтується на партнерстві між учнем, учителем і батьками; орієнтація на потреби учня в освітньому процесі та дитиноцентризм.

Для їх реалізації сучасний вчитель зобов'язаний постійно професійно розвиватися, орієнтуючись на освітні потреби учня та партнерство з ним та його батьками. При цьому, передбачається, що творчий та відповідальний вчитель, який постійно працює над собою, отримає академічну свободу. Тобто, він буде готувати власні авторські навчальні програми, власноруч обирати підручники, методи, стратегії, способи та засоби навчання; активно виражати власну фахову думку. Держава гарантуватиме йому свободу від втручання у професійну діяльність. Змінюється і сама роль учителя, який тепер виступатиме як коуч, фасилітатор, тьютор, модератор індивідуальної освітньої траєкторії дитини.

Поглибленого розуміння вимог до вчителя дозволив аналіз десяти ключових компетентностей, які мають бути сформовані в учнів. Особливу увагу звернемо на основні компетентності у природничих науках та технологіях. Саме в них 
закладені наукове розуміння природи і сучасних технологій, здатність застосовувати його в практичній діяльності; уміння застосовувати науковий метод, спостерігати, аналізувати, формулювати гіпотези, збирати дані, проводити експерименти, аналізувати результати. Отже, вчитель має залучити учнів до навчальнодослідницької роботи з метою формування в них дослідницької компетентності. Відсутність конкретизації цієї діяльності дає нам підстави стверджувати, що такими можуть бути будь-які елементи дійсності, а отже навчальнодослідницька робота повинна бути організована як у межах окремих навчальних предметів, так і досліджень, які базуватимуться на міжпредметних зв'язках.

У Новій українській школі реалізуються засади особистісно-орієнтованої моделі освіти, яка вимагає від школи максимального врахування прав дитини, її здібностей, потреб та інтересів. Це дозволяє на практиці реалізувати принцип дитиноцентризму. Таким чином, кожен викладач має застосовувати методи наукового пізнання 3 метою визначення індивідуальних особливостей кожного учня та розробляти для нього оптимальну методику навчання. Отже, аналіз концептуальних положень Нової української школи дозволив окреслити головні вимоги до вчителя в сучасних умовах: постійний професійний розвиток; формування в учнів дослідницької компетентності; побудова освітнього процесу на основі результатів досліджень особистості учня.

Підвищені вимоги до реалізації у професійній діяльності вчителя дослідницької роботи вимагають сформованості у нього дослідницької компетентності. Здійснимо аналіз сутності цього поняття з метою визначення його змісту в умовах реформування системи освіти та запровадження вимог Нової української школи.

Н. Кузьміна, розглядаючи професійнопедагогічну компетентність викладача, серед спеціальних компетентностей виділяє наукову. Вона, за визначенням вченої, включає дві складові: першу - знання науки (iсторії, методології та методів дослідження, володіння системою понять) i другу - навички та вміння використовувати наукові знання на практиці. Тож для забезпечення трансформації наукових знань у засіб вирішення педагогічних задач, володіння науково-педагогічною компетентністю $\epsilon$ необхідною та обов'язковою умовою формування професіоналізму фахівця $[4,90]$. Отже, услід за Н. Кузьміною, ми уважаємо, що науковопедагогічна компетентність передбачає володіння вчителем Нової української школи знаннями, навичками та вміннями, необхідними для трансформації наукових знань у засіб вирішення ним педагогічних задач. Але таке визначення сьогодні слід уточнити відповідно до сучасних умов розвитку освіти. Наведемо результати цієї роботи.

Аналізуючи сутність дослідницької компетентності вчителя, О. Бережнова визначає iii як особливу функціональну систему психіки i взаємопов'язану з нею цілісну сукупність якостей людини, які забезпечують йому можливість бути ефективним суб'єктом цієї діяльності $[1,56]$. На нашу думку, таке визначення не враховує особливостей дослідницької діяльності педагога та концентрується виключно на психологічному аспекті. Л. Бурчак визначає дослідницьку компетентність майбутнього вчителя хімії, як “якість, що проявляється в потребі особистості володіти методологією наукової творчості; умінні спостерігати й аналізувати, висувати гіпотези щодо вирішення дискусійних питань; виконувати дослідницьку роботу; вмінні проводити педагогічні дослідження, організовувати учнівський експеримент; узагальнювати та передбачати наслідки дослідницької діяльності в процесі навчання у закладах вищої освіти та в подальшій професійній діяльності" $[2,6]$. Нам імпонує те, що автор підкреслює важливість мотиваційного компоненту внутрішньої потреби особистості у дослідницькій діяльності та розкриває основні уміння для ii реалізації. У дослідженні О. Норкіної дослідницька компетентність визначається як інтегрована якість педагога, що характеризується вмотивованістю та ціннісним ставленням учителя до дослідницької діяльності, цілісною системою необхідного для цього знань, умінь, навичок та особистісних якостей, що відбиваються у готовності та здатності здійснювати власну дослідницьку діяльність задля підвищення якості математичної освіти учнів [5, 3]. Як на нас, у наведеному визначенні не врахована діяльність вчителя щодо включення учнів у дослідницьку роботу.

Дослідницьку компетентність майбутніх учителів початкової школи розглядає i К. Степанюк та визначає їі “як інтегральну характеристику особистості, що містить сукупність вимог до самостійної пізнавальної діяльності, оволодіння способами діяльності у нестандартних ситуаціях та визначає готовність майбугніх учителів до їх використання упрофесійній діяльності" [9, 273]. На нашу думку, наведене визначення $є$ досить узагальненим і таким, що не відображає специфікудослідницької роботи вчителя. 
На думку Л. Голуб, дослідницька компетентність педагога $\epsilon$ невіддільним компонентом загальної і професійної освіченості - характеристики особистості педагога, здатного ефективно відтворювати та здійснювати способи дослідницької діяльності з метою пошуку знань 3 вирішення освітніх проблем, побудови освітнього процесу у відповідності цінностей-цілей сучасної освіти, місією освітнього закладу, освітнього результату, який бажається [3, 11]. Наведене визначення чітко розкриває мету здійснення дослідницької діяльності вчителя та акцентує увагу на практичному значенні іiі результатів.

Як інтегровану характеристику, яка визначає здатність педагога до психолого-педагогічної дослідницької діяльності, що включає знання іiі основних компонентів та уміння з їх реалізації, стійке визнання важливості цієї діяльності для вирішення професійних дослідницьких задач в умовах модернізації освіти, розглядає дослідницьку компетентність Т. Шкеріна $[11,8]$.

Загалом, аналіз показав, що усі наведені визначення, не дивлячись на розходження у трактуванні, єднає одне - вони практично не враховують особистість дослідника, тим самим нівелюючи суть компетентнісного підходу.

Наведемо декілька визначень, де цей недолік усунено. Так, Ю. Риндіна дослідницьку компетентність вчителя розглядає на основі аксіологічного підходу і розуміє ії як інтегральну характеристику, що проявляється в його готовності зайняти активну дослідницьку позицію по відношенню до своєї діяльності та до себе, як їі суб' єкту. При цьому, під поняттям “дослідницька позиція" автор слушно розуміє систему мотив педагога, мотиваційно-ціннісного ставлення до себе, інших, дослідницької діяльності [7, 14].

У роботі С. Сисоєвої дослідницька компетентність розглядається як “інтегрована особистісно-професійна якість фахівця, яка відображає мотивацію до наукового пошуку, рівень володіння методологією педагогічного дослідження, особистісно-значущими якостями дослідника, зокрема такими, як інноваційне мислення, здатність до творчої та інноваційної діяльності" [8, 10]. На нашу думку, вказане визначення в повній мірі розкриває сутність поняття, однак, потребують додаткового роз'яснення поняття “інноваційне мислення", “здатність до творчої та інноваційної діяльності”, в контексті професійної діяльності вчителя.

Ураховуючи наведені визначення та спираючись на власний досвід, надамо авторське трактування дослідницької компетентністі вчителя як його інтегрованої особистісно-професійної якості, що відображає мотивацію до наукового пошуку, рівень володіння методологією здійснення дослідження у практичній площині, сформованість особистісно-значущих якостей, як умов реалізації його індивідуальної дослідницької траєкторії та системного залучення учнів до навчальнодослідницької роботи.

Уточнимо сутність складової “індивідуальна дослідницька траєкторія вчителя”. На необхідності іiі існування наголошує І. Попович, досліджуючи формування дослідницьких умінь майбутнього педагога у Великій Британії. Автор зазначає, що “дослідницька парадигма в освіті культивує ціннісне ставлення до професійної педагогічної діяльності, оскільки в її контексті забезпечуються умови для побудови індивідуальної дослідницької траєкторії” [6, 7]. Однак, автором не розкривається характеристика цього поняття. На нашу думку, індивідуальна дослідницька траєкторія вчителя передбачає здійснення дослідницької діяльності з урахуванням власних можливостей, потреб, методів її реалізації, тобто індивідуального темпу, рівня, термінів здійснення, плану виконання, способів оприлюднення та впровадження отриманих результатів роботи. Індивідуальна дослідницька траєкторія дозволяє врахувати індивідуальні пошукові потреби й особистісно-професійні запити вчителя-дослідника, його досвід та рівень підготовки, психофізіологічні та когнітивні особливості, спрогнозувати професійний розвиток на основі вирішення освітніх проблем на науковій основі.

Висновки. Визначено, що формування дослідницької компетентності педагогів $є$ необхідною умовою їхнього становлення у Новій українській школі, яка вивела на новий рівень актуальності значення дослідницької парадигми. Аналіз психолого-педагогічної літератури дозволив встановити, що дослідницьку компетентність цих фахівців слід трактувати як інтегровану особистісно-професійну якість, що відображає мотивацію до наукового пошуку, рівень володіння методологією здійснення дослідження упрактичній площині, сформованість особистіснозначущих якостей, як умов реалізації його індивідуальної дослідницької траєкторії та системного залучення учнів до навчальнодослідницької роботи. Розкрито загальну характеристику складової “індивідуальна дослідницька траєкторія вчителя”. Структура дослідницької компетентності вчителя Нової української школи та модель їі формування будуть розглянуті у подальших дослідженнях. Окремо будуть представлені результати роботи щодо 
формування у вчителя умінь проектувати індивідуальну дослідницьку траєкторію.

\section{ЛIТЕРАТУРА}

1. Бережнова Е.В. Профессиональная компетентность как критерий качества подготовки будущих учителей / Е.В. Бережнова // Инновационная модель подготовки учителя в системе непрерывного психологопедагогического образования: Всероссийская научнопракт. конф., посвященная году учителя в РФ. В 2-х ч. Ч. 1. - Казань: Магариф- Вакыт, 2011. - С. 54-57.

2. Бурчак Л.В. Формування дослідницької компетентності майбутнього вчителя хімії в системі вищої освіти: автореф. дис. на здобуття наук. ступеня канд. пед. наук: спец. 13.00.04 "Теорія та методика професійної освіти” / Л.В. Бурчак. Полтава, 2011.-20 с.

3. Голубь Л.А. Через исследовательскую деятельность - к качеству образовательного результата /Л.А. Голубь // Традиции и инновации в образовании. Ижевск: Издательство ИПК и ПРО УР, 2006. - С. 9 - 13.

4. Кузьмина Н.В. Профессионализм личности преподавателя и мастера производственного обучения / Н.В. Кузьмина. - М.: Высш. шк., 1990. - 119 с.

5. Норкіна О.В. Розвиток дослідницької компетентності вчителів математики засобами інформаційно-комунікативних технологій: автореф. дис. на здобуття наук. ступеня канд. пед. наук: спец. 13.00.04 “Теорія та методика професійної освіти" / О.В. Норкіна. Умань, 2017. - $23 \mathrm{c}$.

6. Попович І.С. Формування дослідницьких умінь майбугнього вчителя в університетах Великої Британії : автореф. дис. на здобуття наук. ступеня канд. пед. наук: спец. 13.00.04 "Теорія та методика професійної освіти” / І.С. Попович. Тернопіль, 2018. - 22 с.

7. Риндина Ю.В. Становление и развитие исследовательской компетентности будущего учителя: автореф. дис. на соиск. уч. степ. канд. пед. пед. наук: спец. 13.00.08 "Теория и методика профессионального образования” / Ю.В. Риндина. Новокузнецк, 2012. -24 с.

8. Сисоєва С. О. Розвиток дослідницької компетентності викладачів вищої школи: навчальний посібник / С. О. Сисоєва, Л. В. Козак // Київ. ун-т ім. Б. Грінченка. - К.: ТОВ "Видавниче підприємство “ЕДЕЛЬВЕЙС”, 2016. - 155 с.

9. Степанюк К. Дослідницька компетентність як складова дослідницьких умінь майбутніх учителів початкової школи / К. Степанюк // Витоки педагогічної майстерності. - 2012. - Вип. 9. - С. 271-275.

10. Типова освітня програма для закладів загальної середньої освіти [Електронний ресурс]. Режим доступу до ресурсу: http://nus.org.ua/news/opublikuvaly-typoviosvitni-programy-dlya-1-2-klasiv-nush-dokumenty/.

11. Шкерина Т.О. Формирование исследовательской компетентности будущих бакалавров педагоговпсихологов в ВУЗе: автореф. дис. на соиск. уч. степ. канд. пед. пед. наук: спец. 13.00.08 “Теория и методика профессионального образования” / Т.О. Шкерина Красноярск, 2013. -23 с.

\section{REFERENCES}

1. Berezhnova, E.V. (2011). Professionalnaya kompetentnost kak kriteriy kachestva podgotovki buduschih uchiteley [Professional competence as a criterion for the quality of the training of future teachers ]. Kazan: Magarif- Vakyt, pp. 54 - 57. [in Russian].

2. Burchak, L.V. (2011). Formuvannya doslidnyczkoyi kompetentnosti majbutnogo vchytelya ximiyi v systemi vyshhoyi osvity [Formation of research competence of the future teacher of chemistry in the system of higher education]. Extended abstract of candidate's thesis. Poltava, 20 p. [in Ukrainian].

3. Golub, L.A. (2006). Cherez issledovatelskuyu deyatelnost $-k$ kachestvu obrazovatelnogo rezultata [Through research activities - to the quality of educational outcomes]. Izhevsk: Publishing house IPK and PRO UR, pp. 9 - 13. [in Russian].

4. Kuzmina, N.V. (1990). Professionalizm lichnosti prepodavatelya $i$ mastera proizvodstvennogo obucheniya [Professionalism of the personality of the teacher and the master of production training ]. Moscow. Ext. Shk., 119 p. [in Russian].

5. Norkina, O.V. (2017). Rozvytok doslidnyczkoyi kompetentnosti vchyteliv matematyky zasobamy informacijno-komunikatyvnyx texnologij [Development of research competence of teachers of mathematics by means of information and communication technologies]. Extended abstract of candidate's thesis. Uman, 23 p. [in Ukrainian].

6. Popovych, I. S (2018). Formuvannya doslidnyczkyx umin majbutnogo vchytelya $v$ universytetax Velykoyi Brytaniyi [Formation of future teacher's research skills at UK universities]. Extended abstract of candidate's thesis. Ternopil, 22 p. [in Ukrainian].

7. Rindina, Yu.V. (2012). Stanovlenie i razvitie issledovatelskoy kompetentnosti buduschego uchitelya [Formation and development of the research competence of the future teacher]. Extended abstract of candidate's thesis. Novokuznetsk, 24 p. [in Russian].

8. Sysoyeva, S. O. (2016). Rozvytok doslidnyczkoyi kompetentnosti vykladachiv vyshhoyi shkoly: navchalnyj posibnyk [Development of Research Competence of Teachers of Higher Education: a manual]. Kyiv: "Edelweiss Publishing Company" LLC, 155 p. [in Ukrainian].

9. Stepanyuk, K. (2012). Doslidnyczka kompetentnist yak skladova doslidnyczkyx umin majbutnix uchyteliv pochatkovoyi shkoly [Research competence as a component of research skills of future primary school teachers]. Origins of pedagogical skill. Issue 9, pp.271 275. [in Ukrainian].

10. Typova osvitnya programa dlya zakladiv zagalnoyi serednoyi osvity [Electronic resource]. Available at: http:/ /nus.org.ua/news/opublikuvaly-typovi-osvitni-programydlya-1-2-klasiv-nush-dokumenty/. [in Ukrainian].

11. Shkerina, T.O. (2013). Formirovanie issledovatelskoy kompetentnosti buduschih bakalavrov pedagogovpsihologov v VUZe [Formation of research competence of future bachelors of psychologists in higher education]. Extended abstract of candidate's thesis. Krasnoyarsk, 23 p. [in Russian].

Стаття надійшла до редакції 26.11.2018 